\title{
Fertilization of Eucalyptus Stands at Advanced Ages in Minas Gerais, Brazil
}

\author{
Laís Silva $^{1}$ (D), Reynaldo Santana ${ }^{2}$ (D), Francisco Gomes ${ }^{3}$ (D), Marcio Oliveira² (D), \\ Guilherme Freitas ${ }^{2}$ \\ ${ }^{1}$ Instituto de Ciências Agrárias - IAF, Universidade Federal de Viçosa - UFV, Florestal/MG, Brasil \\ ${ }^{2}$ Programa de Pós-graduação em Ciência Florestal, Universidade Federal dos Vales do Jequitinhonha e Mucuri - UFVJM, \\ Diamantina/MG, Brasil \\ ${ }^{3}$ Gerdau Florestal S/A, Três Marias/MG, Brasil
}

\begin{abstract}
This study evaluated the response to fertilization at advanced ages in Eucalyptus stands. Fertilization at advanced ages (FA) was applied in stands managed according to tall shaft and coppice regimes. All stands received operational fertilization from the company. It was used as the basis to the network of continuous forestry inventory plots (P-IFC) of the company. Connected to the P-IFC, twin-plots received FA throughout four age classes, 30 to 35,42 to 47,54 to 59 and 66 to 70 months. The FA presented a biological response and provided volumetric gains of 17 and $51 \%$ for stands with tall shaft and coppice, respectively. The most significant responses to the FA was seen at younger ages of the forest in the tall shaft regime. Despite the biological response, the volumetric gains did not provide financial returns in either regime due to the elevated doses applied.
\end{abstract}

Keywords: silviculture, forest nutrition, forest management. 


\section{INTRODUCTION}

In recent decades in Brazil the average gains in productivity of wood from 10 to $39 \mathrm{~m}^{3} \mathrm{ha}^{-1} \mathrm{year}^{-1}$ in Eucalyptus stands have been observed. These gains are mainly attributed to an evolution in forestry practices and to genetic improvements (Gonçalves et al., 2008). According to Stape et al. (2010), the use of mineral fertilizers corresponds, on average, to $30 \%$ of the gains in productivity.

Fertilization in Eucalyptus plantations is normally carried out between the pre-planting phase and the canopy closure. After two years of age, fertilization is reduced or stopped completely (Silva et al., 2013). A direct relation between biomass production and nutrient accumulation was observed by Santana et al. (2008). These authors observed that $70 \%$ of the total nutrient demand of Eucalyptus plantations in Brazil is accumulated up until 4.5 years of age. Between planting and the maximum leaf area index, the stand shows high levels of nutrient absorption and elevated metabolic activity, factors that explain the greater response to fertilization at a younger age (Gonçalves et al., 2013). After the canopy closure phase, the biochemical cycle becomes gradually more established and tends to meet part of the nutritional demand of the stand. The nutrient cycling associated with the fertilization applied during the initial years is considered adequate to satisfy the total demand of the stand because soluble and relatively insoluble fertilizers are used with the intention of providing nutrients throughout the whole cycle. Consequently, it is expected that the plantations are not responsive to the application of nutrients at advanced ages.

Despite this, studies seeking to analyze the nutritional limitations and potential productivity of Eucalyptus have shown a response to fertilization at ages older than two years when very elevated doses of nutrients are applied (Stape et al., 2006; Ferreira \& Stape, 2010; Silva et al., 2016). According to the cited authors, the increase in productivity due to fertilization at advanced ages is influenced, amongst other factors, by the stage of development of the forest, soil and climatic conditions, genetic material and type of forestry management adopted. The knowledge of the probability of response to fertilization and its economic viability (Ferreira \& Stape, 2010) and the classification of responsive and non-responsive sites (Fisher \& Binkley, 2000) are important factors to be considered in making forestry management decisions.

Different to management by tall shaft regime, there have been very little studies on the responses to fertilization in coppice regimes. Generally, the initial fertilization of the stand in coppice regimes takes place after sprout thinning between eight and eighteen months post-harvest. During the phase prior to fertilization, the growth of the stand depends on the nutrient cycling of forest debris, ground cover and the nutrients available in the soil. Reports regarding a drop in productivity during the second rotation in comparison with the first are common (Miranda et al., 1998a, b). Part of the loss of productivity of the stands in the second rotation is attributed to the management adopted in sprout thinning and later fertilization.

Given this, this study aims to evaluate the response to fertilization at advanced ages of Eucalyptus stands under tall shaft and coppice regimes in the state of Minas Gerais.

\section{MATERIALS AND METHODS}

The present study was realized in clonal stands of Eucalyptus, planted in six regions (R1; R2; R3; R4; R5; and R6) in the state of Minas Gerais (Table 1).

To evaluate the potential for response to fertilization at advanced ages (FA), 142 twin-plots were planted (Stape et al., 2006) connected to the 142 plots of the network of the continuous forestry inventory (P-IFC). The plots chosen represented stands in four age classes (CLI). The first was between 30 and 35 months, the second between 42 and 47 months, the third between 54 and 59 months, and the fourth between 66 and 70 months. The study evaluated 244 circular parcels, with 60 trees per parcel, planted in spaces varying from 4.9 to $9.5 \mathrm{~m}^{2}$ per plant, with 15 clones under two management regimes, tall shaft and coppice (Table 2).

The twin-plots were planted between March and May of 2011, set in five rows at the end of the continuous forestry inventory, with the same soil type and slope.

The evaluated treatments were organized in the following way: Control (C) - operational fertilization (Table 3) represented by the plots of continuous forestry inventory, which received the best forestry practices of the company; fertilization at advanced 
Table 1. The main characteristics of the study area.

\begin{tabular}{|c|c|c|c|c|c|c|c|}
\hline \multirow{2}{*}{ Region } & \multirow{2}{*}{ City } & Latitude (S) & Elv. & \multirow{2}{*}{ Climate $^{\mathrm{b}}$} & $\mathbf{T}$ & \multirow{2}{*}{$\begin{array}{c}\mathbf{R} \\
(\mathrm{mm})\end{array}$} & \multirow{2}{*}{ Soil order } \\
\hline & & Longitude $(\mathrm{W})^{\mathrm{a}}$ & $(\mathbf{m})$ & & $\left({ }^{\circ} \mathrm{C}\right)$ & & \\
\hline \multirow{2}{*}{ R1 } & Três Marias & $45^{\circ} 15^{\prime} 16^{\prime \prime} \mathrm{S} 18^{\circ} 12^{\prime} 32^{\prime \prime} \mathrm{O}$ & 735 & Cwa & 21 & 1396 & \multirow{2}{*}{ Oxisols } \\
\hline & Lassance & $17^{\circ} 53^{\prime} 13^{\prime \prime} \mathrm{S} 44^{\circ} 34^{\prime} 36^{\prime \prime O}$ & 790 & Aw & 21 & 1335 & \\
\hline $\mathrm{R} 2$ & Rio Pardo de Minas & $15^{\circ} 36^{\prime} 36^{\prime \prime} \mathrm{S} 42^{\circ} 32^{\prime} 23^{\prime \prime} \mathrm{O}$ & 900 & Cwa & 21 & 903 & Oxisols \\
\hline \multirow{7}{*}{ R3 } & Ibertioga & $21^{\circ} 25^{\prime} 52^{\prime \prime} \mathrm{S} 43^{\circ} 57^{\prime} 58^{\prime \prime} \mathrm{O}$ & 1099 & Cwb & 17 & 1555 & \multirow{7}{*}{$\begin{array}{l}\text { Oxisols and } \\
\text { Ultisols }\end{array}$} \\
\hline & São João Del Rei & $21^{\circ} 8^{\prime} 82^{\prime \prime} \mathrm{S} 44^{\circ} 15^{\prime} 40^{\prime \prime} \mathrm{O}$ & 1007 & Cwb & 18 & 1575 & \\
\hline & Luminárias & $21^{\circ} 30^{\prime} 40^{\prime \prime} \mathrm{S} 44^{\circ} 54^{\prime} 11^{\prime \prime} \mathrm{O}$ & 1027 & Cwb & 18 & 1594 & \\
\hline & Ingaí & $21^{\circ} 24^{\prime} 30^{\prime \prime} \mathrm{S} 44^{\circ} 55^{\prime} 19^{\prime \prime} \mathrm{O}$ & 963 & Cwb & 18 & 1614 & \\
\hline & Nazareno & $21^{\circ} 13^{\prime} 00^{\prime \prime} \mathrm{S} 44^{\circ} 36^{\prime} 41^{\prime \prime} \mathrm{O}$ & 935 & Cwb & 18 & 1689 & \\
\hline & Santo Antônio do Amparo & $20^{\circ} 56^{\prime} 47^{\prime \prime} \mathrm{S} 44^{\circ} 55^{\prime} 69^{\prime \prime} \mathrm{O}$ & 969 & Cwb & 18 & 1709 & \\
\hline & Ibituruna & $21^{\circ} 9^{\prime} 80^{\prime \prime} \mathrm{S} 44^{\circ} 44^{\prime} 51^{\prime \prime O}$ & 892 & Cwb & 19 & 1714 & \\
\hline $\mathrm{R} 4$ & João Pinheiro & $17^{\circ} 44^{\prime} 34^{\prime \prime} \mathrm{S} 46^{\circ} 10^{\prime} 31^{\prime \prime} \mathrm{O}$ & 680 & Aw & 22 & 1419 & $\begin{array}{l}\text { Oxisols and } \\
\text { Entisols }\end{array}$ \\
\hline R5 & Buritizeiro & $17^{\circ} 21^{\prime} 10^{\prime \prime} \mathrm{S} 44^{\circ} 57^{\prime} 29^{\prime \prime} \mathrm{O}$ & 658 & Aw & 22 & 1252 & Entisols \\
\hline \multirow{2}{*}{ R6 } & Olhos D’água & $17^{\circ} 23^{\prime} 47^{\prime \prime} \mathrm{S} 43^{\circ} 34^{\prime} 28^{\prime \prime} \mathrm{O}$ & 866 & Cwa & 20 & 1232 & \multirow{2}{*}{$\begin{array}{l}\text { Oxisols and } \\
\text { Ultisols }\end{array}$} \\
\hline & Diamantina & $18^{\circ} 14^{\prime} 40^{\prime \prime} \mathrm{S} 43^{\circ} 36^{\prime} 10^{\prime \prime} \mathrm{O}$ & 998 & Cwb & 19 & 1329 & \\
\hline
\end{tabular}

a'Location of the municipal and district headquarters of the state of Minas Gerais, classification of the Institute of Applied Geosciences (IGA, 2015). ${ }^{\text {b}}$ Köppen climate classification. Elv. = elevation $(\mathrm{m}) ; \mathrm{T}=$ Average annual temperature $\left({ }^{\circ} \mathrm{C}\right) ; \mathrm{R}=\mathrm{Rainfall}(\mathrm{mm})$. (Alvares et al., 2013; Meneses et al., 2015).

Table 2. Spacing, clone, age class (CLI) and number of plots per region and management regime.

\begin{tabular}{|c|c|c|c|}
\hline Spacing $\left(\mathrm{m}^{2}\right.$ tree $\left.^{-1}\right)$ & Clone/Region & CLI (month) & Number of plots \\
\hline $8.4^{*}$ & GG157R1 & 1 & 4 \\
\hline $8.4^{*}$ & GG680/R1 & 1 & 1 \\
\hline $8.4^{\star}$ & GG100/R1 & 1 & 2 \\
\hline $8.4^{*}$ & GG702/R1 & 1 & 1 \\
\hline $8.4^{*}$ & GG739/R1 & 1 & 1 \\
\hline $8.4^{*}$ & GG100/R1 & 2 & 1 \\
\hline $8.4^{\star}$ & GG157/R1 & 2 & 2 \\
\hline $8.4^{*}$ & GG680/R1 & 2 & 4 \\
\hline $8.4^{*}$ & GG702/R1 & 2 & 1 \\
\hline $8.4^{*}$ & GG680/R1 & 3 & 2 \\
\hline $8.4^{*}$ & GG100/R1 & 3 & 5 \\
\hline $8.4^{*}$ & GG702/R1 & 3 & 4 \\
\hline $8.4^{*}$ & GG157/R1 & 4 & 2 \\
\hline $8.4^{*}$ & GG702/R1 & 4 & 1 \\
\hline $9.5^{*}$ & GG680/R1 & 4 & 1 \\
\hline $8.2^{*}$ & GG100/R1 & 4 & 1 \\
\hline $8.2^{*}$ & GG680/R1 & 4 & 1 \\
\hline $8.4^{\star}$ & GG100/R1 & 4 & 3 \\
\hline $8.2^{\star}$ & GG100/R1 & 4 & 1 \\
\hline $9.1^{\star *}$ & GG100/R1 & 1 & 7 \\
\hline $9.1^{\star *}$ & GG170/R1 & 1 & 1 \\
\hline $9.1^{\star *}$ & GG100/R1 & 2 & 7 \\
\hline $9.1^{\star \star}$ & GG157/R1 & 2 & 2 \\
\hline $9.1^{\star *}$ & GG170/R1 & 2 & 2 \\
\hline $9.1^{\star *}$ & GG2333/R1 & 2 & 1 \\
\hline $9.1^{\star *}$ & GG2334/R1 & 2 & 1 \\
\hline $8.4^{*}$ & GG680/R2 & 1 & 2 \\
\hline
\end{tabular}

${ }^{*}$ tall shaft. ${ }^{* *}$ coppice. CLI $=$ age classes between 30 and 35 months; CLI2 $=$ age classes between 42 and 47 months; CLI3 = age classes between 54 and 59; CLI $4=$ age classes between 66 and 70 months. 
Table 2. Continued...

\begin{tabular}{|c|c|c|c|}
\hline Spacing $\left(\mathrm{m}^{2}\right.$ tree $\left.^{-1}\right)$ & Clone/Region & CLI (month) & Number of plots \\
\hline $8.4^{*}$ & GG2335/R2 & 2 & 2 \\
\hline $8.4^{\star}$ & GG702/R2 & 2 & 1 \\
\hline $8.4^{*}$ & GG100/R2 & 3 & 4 \\
\hline $8.4^{*}$ & GG702/R2 & 3 & 1 \\
\hline $8.4^{*}$ & GG100/R2 & 4 & 1 \\
\hline $8.4^{\star}$ & GG2335/R2 & 4 & 2 \\
\hline $8.4^{*}$ & GG672/R2 & 4 & 1 \\
\hline $8.4^{*}$ & GG680/R2 & 4 & 5 \\
\hline $8.4^{*}$ & GG702/R2 & 4 & 1 \\
\hline $9.0^{*}$ & GG100/R2 & 4 & 1 \\
\hline $9.0^{*}$ & GG2335/R2 & 4 & 1 \\
\hline $9.0^{*}$ & GG100/R3 & 1 & 1 \\
\hline $9.0^{*}$ & GG2335/R3 & 1 & 5 \\
\hline $6.0^{*}$ & GG680/R3 & 2 & 1 \\
\hline $7.5^{\star}$ & GG47/R3 & 2 & 1 \\
\hline $7.5^{\star}$ & GG62/R3 & 2 & 1 \\
\hline $7.5^{*}$ & GG680/R3 & 2 & 1 \\
\hline $8.4^{*}$ & GG68/R3 & 2 & 1 \\
\hline $8.4^{*}$ & GG680/R3 & 2 & 2 \\
\hline $6.0^{*}$ & GG100/R3 & 3 & 1 \\
\hline $6.0^{*}$ & GG24/R3 & 3 & 1 \\
\hline $7.5^{\star}$ & GG157/R3 & 3 & 1 \\
\hline $8.4^{*}$ & GG100/R3 & 3 & 1 \\
\hline $8.4^{\star}$ & GG2335/R3 & 3 & 1 \\
\hline $8.4^{*}$ & GG100/R3 & 4 & 2 \\
\hline $8.4^{*}$ & GG157/R3 & 4 & 2 \\
\hline $8.4^{*}$ & GG2335/R3 & 4 & 1 \\
\hline $4.9^{*}$ & GG2333/R4 & 1 & 1 \\
\hline $4.9^{*}$ & GG2335/R4 & 1 & 2 \\
\hline $8.4^{*}$ & GG100/R4 & 1 & 1 \\
\hline $8.4^{*}$ & GG2335/R4 & 1 & 2 \\
\hline $8.4^{*}$ & GG680/R4 & 1 & 2 \\
\hline $8.4^{*}$ & GG702/R4 & 1 & 1 \\
\hline $8.4^{*}$ & GG702/R4 & 1 & 1 \\
\hline $8.4^{*}$ & GG100/R4 & 2 & 1 \\
\hline $8.4^{*}$ & GG680/R4 & 2 & 3 \\
\hline $8.4^{*}$ & GG702/R4 & 2 & 2 \\
\hline $8.4^{*}$ & GG100/R4 & 3 & 5 \\
\hline $8.4^{*}$ & GG680/R4 & 3 & 1 \\
\hline $8.4^{*}$ & GG100/R5 & 3 & 2 \\
\hline $8.4^{*}$ & GG2335/R5 & 3 & 1 \\
\hline $8.1^{*}$ & GG100/R5 & 4 & 1 \\
\hline $8.4^{*}$ & GG100/R5 & 4 & 1 \\
\hline $8.4^{*}$ & GG680/R5 & 4 & 1 \\
\hline $9.1^{* *}$ & GG100/R5 & 1 & 1 \\
\hline $9.1^{\star *}$ & GG157/R5 & 1 & 1 \\
\hline $9.1^{\star *}$ & GG2335/R5 & 1 & 1 \\
\hline $9.1^{\star *}$ & GG100/R5 & 2 & 2 \\
\hline $9.1^{* *}$ & GG50/R5 & 2 & 1 \\
\hline $8.4^{*}$ & GG2335/R6 & 1 & 3 \\
\hline $8.4^{*}$ & GG100/R6 & 2 & 1 \\
\hline
\end{tabular}

${ }^{*}$ tall shaft. ${ }^{* *}$ coppice. CLI $=$ age classes between 30 and 35 months; CLI2 = age classes between 42 and 47 months; CLI3 = age classes between 54 and 59; CLI4 $=$ age classes between 66 and 70 months. 
ages (FA) - recommended to eliminate possible nutritional limitations, applied on the twin-plots that had already received the operational fertilization, in stands in tall shaft and coppice regimes, and in the CLI 1, 2, 3 and 4, according to the proposal of Stape et al. (2006). The FA was divided into four applications, the first (FA1) in the establishment of the twin-plots and the others 6 (FA2), 12 (FA3), and 18 (FA4) months later (Table 4).

The trees of the plots ( $\mathrm{C}$ and FA) were measured in the twin-plots installations every six months subsequently, between 2011 and 2013. In each plot, the diameter at $1.30 \mathrm{~m}$ from the ground was measured $(\mathrm{DBH})$ for all 60 trees as well as the total height (HT) of the first seven trees. The height of the remaining 53 trees was estimated using artificial neural networks - ANNs (Özçelik et al., 2013).

To estimate the ANNs, the quantitative entry variables were considered to be age (years) and $\mathrm{DBH}$ $(\mathrm{cm})$, the categorical entry variables were the rotation and genetic material and the output variable was the HT (m). The trained networks were of the multiple

Table 3. Average and standard deviation of the nutrients applied in the operational fertilization by region.

\begin{tabular}{|c|c|c|c|c|c|c|c|c|c|c|}
\hline \multirow{2}{*}{ Region } & \multirow{2}{*}{$\mathbf{n}^{\mathbf{o}}$} & $\mathbf{N}$ & $\mathbf{P}_{2} \mathbf{O}_{5}$ & $\mathrm{~K}_{2} \mathrm{O}$ & $\mathrm{CaO}$ & $\mathrm{MgO}$ & $\mathrm{SO}_{3}$ & B & $\mathrm{Cu}$ & Zn \\
\hline & & \multicolumn{9}{|c|}{ 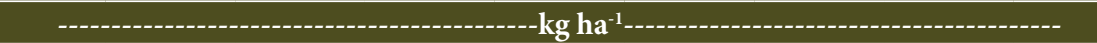 } \\
\hline \multicolumn{11}{|c|}{ Tall shaft } \\
\hline $\mathrm{R} 1$ & 71 & $14^{(7)}$ & $156^{(62)}$ & $177^{(50)}$ & $635^{(234)}$ & $121^{(71)}$ & $22^{(14)}$ & $4^{(1)}$ & $1^{(1)}$ & $3^{(3)}$ \\
\hline $\mathrm{R} 2$ & 38 & $13^{(11)}$ & $107^{(68)}$ & $93^{(52)}$ & $468^{(325)}$ & $208^{(206)}$ & $36^{(35)}$ & $5^{(3)}$ & $1^{(1)}$ & $1^{(1)}$ \\
\hline R3 & 42 & $9^{(5)}$ & $129^{(64)}$ & $102^{(56)}$ & $325^{(256)}$ & $67^{(83)}$ & $13^{(8)}$ & $3^{(1)}$ & $0^{(0)}$ & $1^{(1)}$ \\
\hline $\mathrm{R} 4$ & 43 & $13^{(7)}$ & $191^{(47)}$ & $191^{(30)}$ & $564^{(126)}$ & $206^{(50)}$ & $18^{(11)}$ & $4^{(1)}$ & $0^{(0)}$ & $7^{(1)}$ \\
\hline R5 & 18 & $16^{(7)}$ & $181^{(49)}$ & $131^{(19)}$ & $835^{(233)}$ & $119^{(38)}$ & $19^{(9)}$ & $4^{(1)}$ & $1^{(1)}$ & $2^{(1)}$ \\
\hline R6 & 23 & $10^{(5)}$ & $75^{(28)}$ & $177^{(50)}$ & $428^{(232)}$ & $75^{(41)}$ & $17^{(16)}$ & $5^{(1)}$ & $0^{(0)}$ & $3^{(2)}$ \\
\hline Average & & 13 & 140 & 145 & 543 & 133 & 21 & 4 & 1 & 3 \\
\hline \multicolumn{11}{|c|}{ Coppice } \\
\hline $\mathrm{R} 1$ & 33 & $0^{(0)}$ & $125^{(43)}$ & $83^{(49)}$ & $327^{(175)}$ & $71^{(35)}$ & $0^{(0)}$ & $2^{(1)}$ & $0^{(0)}$ & $0^{(0)}$ \\
\hline R5 & 9 & $0^{(0)}$ & $102^{(46)}$ & $64^{(68)}$ & $129^{(59)}$ & $28^{(17)}$ & $1^{(4)}$ & $1^{(1)}$ & $0^{(0)}$ & $0^{(0)}$ \\
\hline Average & & 0 & 114 & 74 & 228 & 50 & 1 & 2 & 0 & 0 \\
\hline
\end{tabular}

$\mathrm{n}^{\mathrm{o}}=$ Number of compartiments. Values in parentheses refer to standard deviation, because each compartment in which the plot was established received a specific fertilization prescription.

Table 4. Nutrients applied in the fertilization at advanced age (FA).

\begin{tabular}{|c|c|c|c|c|c|c|c|c|c|c|c|c|c|}
\hline \multirow{2}{*}{ Fertilizers } & Dose & $\mathbf{N}$ & $\mathbf{P}_{2} \mathrm{O}_{5}$ & $\mathrm{~K}_{2} \mathrm{O}$ & $\mathrm{CaO}$ & MgO & $\mathrm{SO}_{3}$ & B & $\mathrm{Cu}$ & $\mathrm{Zn}$ & $\mathrm{Fe}$ & Mn & Mo \\
\hline & \multicolumn{13}{|c|}{ 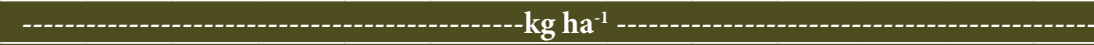 } \\
\hline \multicolumn{14}{|c|}{ FA1 } \\
\hline MAP & 538 & 48 & 258 & - & - & - & - & - & - & - & - & - & - \\
\hline Rima Limistone & 839 & - & - & 0 & 447 & 101 & - & - & - & - & 30 & 5 & - \\
\hline Magnesite & 249 & - & - & - & - & 199 & - & - & - & - & - & - & - \\
\hline Gypsum & 2268 & - & 5 & - & 680 & - & 401 & - & - & - & - & - & - \\
\hline $\mathrm{KCl}+1 \% \mathrm{~B}$ & 403 & - & - & 218 & & - & - & 4 & - & - & - & - & - \\
\hline $\mathrm{NH}_{4} \mathrm{SO}_{4}$ & 627 & 132 & - & - & - & - & 144 & - & - & - & - & - & - \\
\hline Borogram & 10 & - & - & - & - & - & - & 1 & - & - & - & - & - \\
\hline $\mathrm{CuSO}_{4}$ & 30 & - & - & - & - & - & - & - & 3 & - & - & - & - \\
\hline $\mathrm{ZnSO}_{4}$ & 270 & - & - & - & - & - & - & - & - & 27 & - & - & - \\
\hline $\mathrm{MnSO}_{4}$ & 6 & - & - & - & - & - & 1 & - & - & - & - & 2 & - \\
\hline Ammonium Molybdate & 0,9 & - & - & - & - & - & - & - & - & - & - & - & 0,3 \\
\hline \multicolumn{14}{|c|}{ FA2, FA3 e FA4 } \\
\hline MAP & 377 & 34 & 181 & - & - & - & - & - & - & - & - & - & - \\
\hline KCL & 403 & - & - & 218 & - & - & - & - & - & - & - & - & - \\
\hline $\mathrm{NH}_{4} \mathrm{SO}_{4}$ & 696 & 146 & - & - & - & - & 160 & - & - & - & - & - & - \\
\hline
\end{tabular}

$\mathrm{MAP}=$ monoamonic phosphate; $\mathrm{KCl}=$ potassium chloride; $\mathrm{NH}_{4} \mathrm{SO}_{4}=$ ammonium sulphate; $\mathrm{CuSO} 4=$ copper sulphate; $\mathrm{ZnSO}_{4}=$ zinc sulphate; $\mathrm{MnSO}_{4}=$ manganous sulphate. FA1 was applied in the establishment of the twin-plots, and the others 6 (FA2), 12 (FA3) and 18 (FA4) months later. 
layer perceptron type, also known as MLP (Multilayer Perceptron). An ANN was trained for each treatment (C and FA) utilizing the software Statistica 10 (Statsoft, 2010 ), which used $50 \%$ of the data to train the networks, $25 \%$ for the test and 25\% for validation.

Based on the DBH and HT values, the individual volumes were estimated (V - Equation 1) for each tree, in each parcel evaluated, utilizing the Shumacher \& Hall (1933) model,

$$
\operatorname{Ln}(V)=\beta_{0}+\beta_{1} * \operatorname{Ln}(D B H)+\beta_{2} * \ln (H T)+\varepsilon
$$

in which: $L n$ is the Naperian logarithm; $V$ the volume per tree $\left(\mathrm{m}^{3}\right) ; \beta_{0}, \beta_{1}$ and $\beta_{2}$ the model parameters; $D B H$ the diameter at $1.3 \mathrm{~m}$ from the ground $(\mathrm{cm}) ; H T$ the total height of the trees $(\mathrm{m})$; and $\varepsilon$ the random error.

To obtain the initial twin character between the plots $\mathrm{C}$ and FA, plots whose volumes were statistically equal according to T-paired test analysis were chosen, with a level of significance of 0.05 (Figure 1) (Stape et al. 2006).

In each treatment ( $\mathrm{C}$ and $\mathrm{FA}$ ) the volumetric gain ( GV - Equation 2), was expressed by the difference between the volume obtained in the last and first measurements:

$G V=V f_{i}-V 0_{i}$

In which: $G V$ is the volumetric gain $\left(\mathrm{m}^{3} \mathrm{ha}^{-1}\right)$; $V$ the volume $\left(\mathrm{m}^{3} \mathrm{ha}^{-1}\right)$; $f$ the last measurement; 0 the first measurement; and $i$ the treatment.

The response to FA, independent of $\mathrm{R}$ and CLI, was evaluated by comparison with the GV between the treatments $\mathrm{C}$ and FA. For this, the T-paired test was applied, with a level of significance of 0.05 utilizing the Statistic 10 software (Statsoft, 2010). The response to FA (Equation 3) by R and CLI was evaluated using descriptive statistics, obtaining an average of the GV for each treatment ( $\mathrm{C}$ and FA) and comparing them according to the relative difference between the average of $\mathrm{GV}$ of the $\mathrm{FA}$ in relation to the average of the volumetric gain of $\mathrm{C}$ :

$R F A=G V_{F A}-G V_{C}$

in which: RFA is the response to FA in $\mathrm{m}^{3} \mathrm{ha}^{-1}$; and $G V$ is the volumetric gain $\left(\mathrm{m}^{3} \mathrm{ha}^{-1}\right)$.

To evaluate the economic viability of the GV stemming from the FA, a cost benefit analysis according to Kimberley et al. (2004) was carried out for two situations: general analysis (independent of R and CLI) and analysis by CLI. The costs per hectare included expenses for fertilizer and labor $(\mathrm{F} 1$ - R\$ 3,618.9; F2 - R\$ 2,090.0; F3 - R\$ 2,090; F4 - R\$ 2,090). For the calculation of the income, the value of sales of standing wood was considered to be $\mathrm{R} \$ 55.0 \mathrm{~m}^{-3}$. The current values of the costs were deflated according to the General Price Index - internally available at the Fundação Getúlio Vargas (FGV, 2017) as suggested by Nascimento et al. (2016).

The probability of the response to FA, by the $\mathrm{GV}$, was analyzed using five classes according to the frequency of response by plot. The class (CL) was distributed according to the average $(\bar{X})$ and the standard deviation (S): CL1 - R $<\bar{X}-2 S$; CL2 $-\bar{X}-2 S<R<\bar{X}-1 S$; CL3 $-\bar{X}-1 S<R<\bar{X}+1 S$; CL4 $-\bar{X}+1 S<R<\bar{X}+2 S$; and CL5 $-\mathrm{R}>\bar{X}+2 S$.
A

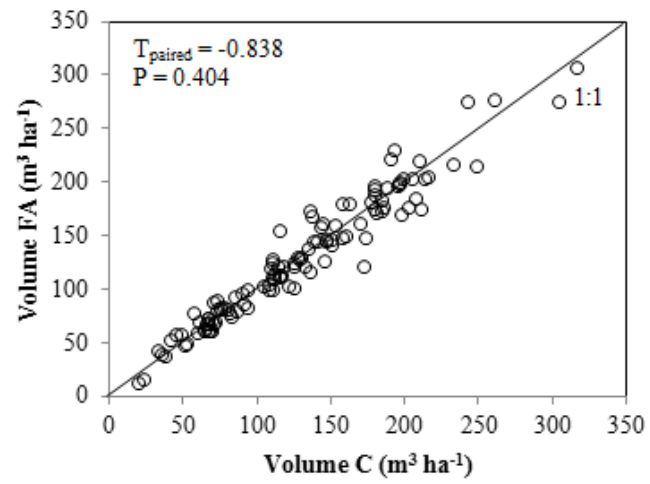

B

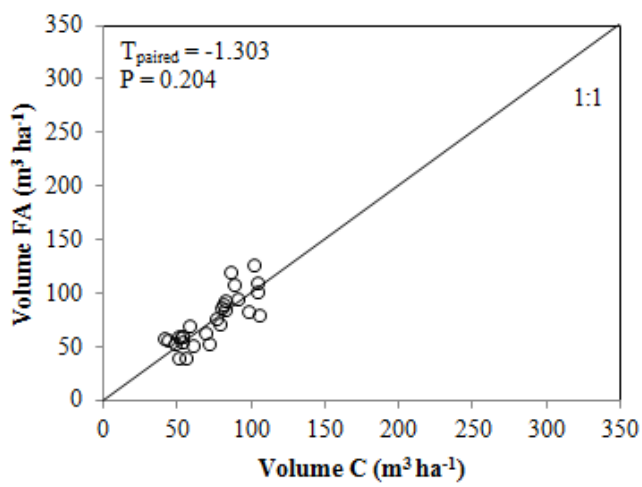

Figure 1. The twin character between the initial volumes of the control (C) and the fertilization at an advanced age (FA) in the stands in tall shaft (A) and coppice (B) regimes. 


\section{RESULTS}

Stands in a tall shaft regime presented, respectively, volumes $\left(\mathrm{m}^{3} \mathrm{ha}^{-1}\right)$ initial averages and mean annual increment - MAI $\left(\mathrm{m}^{3} \mathrm{ha}^{-1}\right.$ year $\left.^{-1}\right)$ - of 128 and 34 for C and 129 and 36 for $\mathrm{FA}$, and for the coppice regime 73 and 26 for $\mathrm{C}$ and 76 and 33 for FA.

The FA provided a positive response in terms of volumetric production in both management regimes (Figure 2). The volumetric gain, independent of age and region, was $17 \%$ greater in the tall shaft $\left(\mathrm{FA}=77 \mathrm{~m}^{3} \mathrm{ha}^{-1}\right.$; $\left.\mathrm{C}=66 \mathrm{~m}^{3} \mathrm{ha}^{-1}\right)$ and $51 \%$ in the coppice $\left(\mathrm{FA}=95 \mathrm{~m}^{3} \mathrm{ha}^{-1}\right.$; $\left.\mathrm{C}=63 \mathrm{~m}^{3} \mathrm{ha}^{-1}\right)$.

A

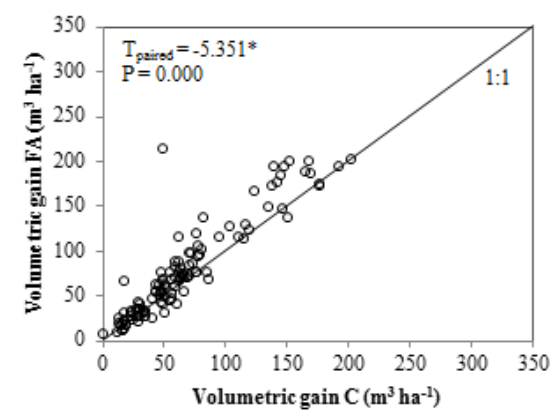

Considering the tall shaft regime, the greatest gain was observed in R6 (39\%) and the least in R2 (6\%) (Table 5). The response to the FA was different depending on the age at the time of application. Stands in the CLI 1 showed volumetric gains of $21 \%$ and those in the CL 4 of $11 \%$. In the coppice regime, gains were above those of the tall shaft regime with values reaching $57 \%$ in the $\mathrm{R} 5$ and $62 \%$ in the CLI 1.

The cost for the FA was the same in all evaluated situations (Table 6). It can be observed that the GV with FA did not present an economic return for stands in tall shaft and coppice regimes, independent of $\mathrm{R}$ and CLI, given that income obtained was much less than

B

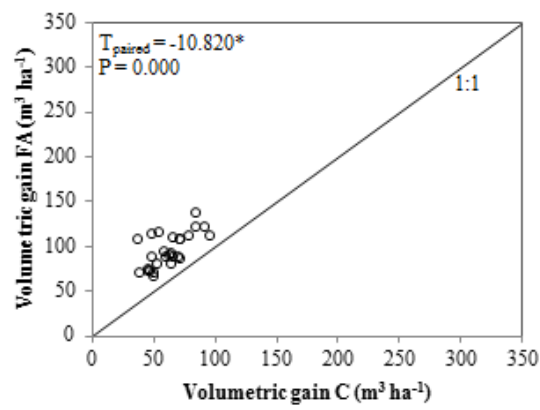

Figure 2. Relationship between the volumetric gains of the control (C) and fertilization at advanced age (FA) in stands with tall shaft (A) and coppice (B) regimes.

Table 5. Average volumetric gains of the control (C) and the fertilization at advanced age (FA) for stands in tall shaft and coppice regimes.

\begin{tabular}{|c|c|c|c|c|c|c|c|c|c|}
\hline \multirow{3}{*}{ Region } & \multirow{3}{*}{ CLI } & \multirow{2}{*}{$I_{0}$} & \multirow{2}{*}{$I_{f}$} & \multirow{3}{*}{$\mathbf{N}$} & \multicolumn{2}{|c|}{ Volumetric gain } & \multirow{2}{*}{$\mathbf{D}_{\mathrm{i}}$} & \multicolumn{2}{|c|}{$\mathrm{CV}$} \\
\hline & & & & & C & FA & & C & FA \\
\hline & & \multicolumn{2}{|c|}{---month--- } & & \multicolumn{2}{|c|}{----m ha $^{3}$ h---- $^{-1}$} & \multicolumn{3}{|c|}{------\%------ } \\
\hline \multicolumn{10}{|c|}{ Tall shaft } \\
\hline $\mathrm{R} 1$ & * & * & * & 38 & 54 & 59 & 8 & 49 & 53 \\
\hline $\mathrm{R} 2$ & * & * & * & 22 & 30 & 31 & 6 & 50 & 51 \\
\hline R3 & * & * & * & 23 & 121 & 152 & 25 & 43 & 35 \\
\hline $\mathrm{R} 4$ & * & * & * & 22 & 70 & 76 & 9 & 58 & 55 \\
\hline R5 & * & * & * & 6 & 62 & 82 & 33 & 39 & 36 \\
\hline R6 & * & * & * & 4 & 50 & 70 & 39 & 45 & 28 \\
\hline ** & 1 & 30 & 54 & 30 & 87 & 106 & 21 & 58 & 53 \\
\hline ** & 2 & 42 & 66 & 25 & 87 & 97 & 11 & 58 & 62 \\
\hline ** & 3 & 54 & 78 & 30 & 60 & 71 & 18 & 46 & 53 \\
\hline$* *$ & 4 & 66 & 80 & 30 & 34 & 38 & 11 & 78 & 90 \\
\hline \multicolumn{10}{|c|}{ Coppice } \\
\hline $\mathrm{R} 1$ & * & * & * & 21 & 62 & 93 & 49 & 22 & 22 \\
\hline R5 & * & * & * & 6 & 64 & 100 & 57 & 37 & 16 \\
\hline$* *$ & 1 & 30 & 55 & 11 & 61 & 99 & 62 & 26 & 21 \\
\hline$* *$ & 1 & 42 & 66 & 16 & 64 & 92 & 44 & 25 & 20 \\
\hline
\end{tabular}

$\mathrm{C}=$ control; $\mathrm{FA}=$ fertilization at advanced age; $\mathrm{CV}=$ coefficient of variation; $\mathrm{I}_{0}=$ Stands age class at the beginning of the experiment; $I_{f}=$ Average age of stands in the last measurement; $N=$ Number of plots; $D_{i}=$ Difference in percentage between the mean volumetric gains of the FA in relation to the $\mathrm{C}$ at the end of the experiment. ${ }^{*}$ Age independent analysis by age. ${ }^{* *}$ Age independent analysis of the region. 
Table 6. Cost of fertilization at advance age (FA) and income obtained from volumetric gains derived from FA in stands with tall shaft and coppice regimes.

\begin{tabular}{|c|c|c|c|}
\hline \multirow{3}{*}{ Type of analysis } & \multirow{2}{*}{ Cost } & \multicolumn{2}{|c|}{ Income } \\
\hline & & Tall shaft & Coppice \\
\hline & 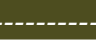 & $-\mathbf{R} \$ \mathbf{h a}^{-1}$ & 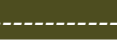 \\
\hline General $^{*}$ & \multirow{5}{*}{13,375} & 605 & 1760 \\
\hline CLI $1^{\star *}$ & & 1045 & 2090 \\
\hline $\operatorname{CLI} 2^{* *}$ & & 550 & 1540 \\
\hline CLI $3^{* *}$ & & 605 & - \\
\hline CLI $4^{* *}$ & & 220 & - \\
\hline
\end{tabular}

${ }^{*}$ Independent of region and age classes. ${ }^{* *}$ Analysis of age classes (CLI): CLI1 between 30 and 35 months; CLI2 between 42 and 47 months; CLI3 between 54 and 59 months; and CLI4 between 66 and 70 months.

A

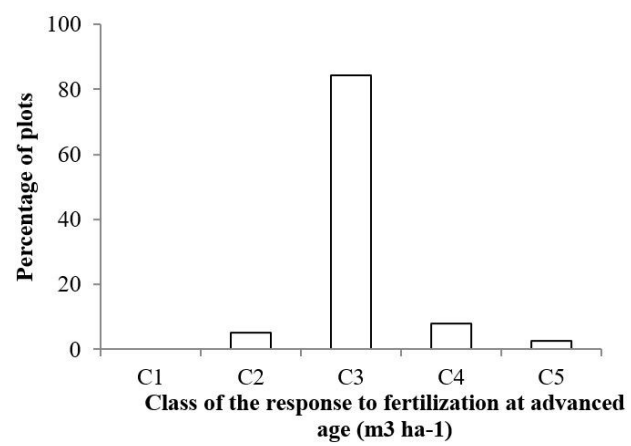

$\mathrm{B}$

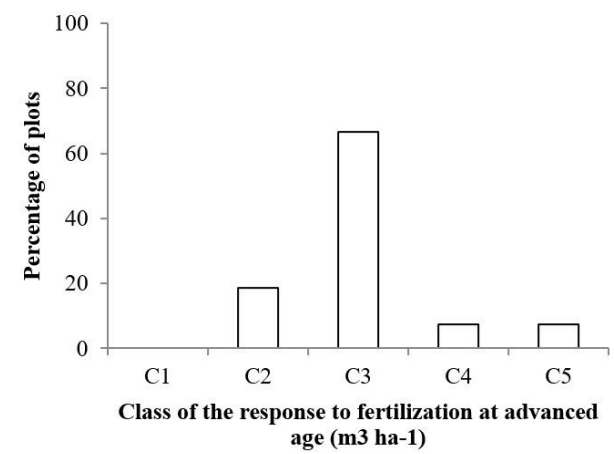

Figure 3. Distribution of the response to fertilization at advanced age of all the parcels, by response class (R): $\mathrm{CL} 1-\mathrm{R}<\bar{X}-2 S$; CL2 $-\bar{X}-2 S<R<\bar{X}-1 S$; CL3 $-\bar{X}-1 S<R<\bar{X}+1 S$;CL4 $-\bar{X}+1 S<R<\bar{X}+2 S$; and CL5 $-\mathrm{R}>\bar{X}+2 S$, for the stands in tall shaft (A) and coppice (B) regimes.

the cost. In analyses only using CLI, it can be observed that the stands that received the FA at younger ages were those presenting the greatest additional incomes.

The probability of the response to FA tended toward normal distribution in the stands in tall shaft and coppice regimes (Figure 3 ). In the tall shaft regime, the average gain was $11 \mathrm{~m}^{3} \mathrm{ha}^{-1}$ with a standard deviation of $22 \mathrm{~m}^{3} \mathrm{ha}^{-1}$. In percentage terms, $38 \%$ of the plots presented responses above the average and 19\% presented more than twice the average. In the coppice regime, the average was $32 \mathrm{~m}^{3} \mathrm{ha}^{-1}$ with a deviation of $15 \mathrm{~m}^{3} \mathrm{ha}^{-1}$ In this regime, $37 \%$ of the plots showed responses above the average and $7 \%$ were more than twice the average.

\section{DISCUSSION}

The response to FA in terms of GV showed an average of $11 \mathrm{~m}^{3} \mathrm{ha}^{-1}$ in tall shaft regimes (Figure 2). Studies carried out in the state of São Paulo agree with these observations. The average gains of 10 and $8.1 \mathrm{~m}^{3} \mathrm{ha}^{-1}$ year-1 were observed, respectively, by Stape et al. (2006) and Ferreira \& Stape (2010). In both studies, the same FA utilized in the present study was used. The operational fertilization utilized was based on the nutritional balance method. This method was developed to achieve desired productivity and guarantee the sustainability of the forestry sites (Gonçalves et al., 2008) with fertilization generally focusing on the first two years of life to guarantee growth until nutrient cycling was established.

Despite the biological response observed with FA, it did not lead to economic viability, given that the additional income derived from GV presented values well below the cost of the fertilizer and the labor for its application (Table 6). Considering the cost benefit analysis by CLI, it was found that the additional income was greater in stands that received FA at a younger age (CLI 1). This fact agrees with the observations 
of Santana et al. (2008) and Gonçalves et al. (2013) where a greater demand for nutrients during younger phases of forest development was demonstrated with a consequent greater potential for response to its application at younger ages. It is underlined that the economic returns from FA were not expected since it was primarily recommended to guard against nutritional shortfalls in the stands.

The average of the MAI in the coppice regime was $23 \%$ lower than the tall shaft regime for operational fertilization. However, a much greater biological response to FA in terms of the tall shaft regime was observed, despite not observing an economic benefit. Probably the unviable economic outcome occurred due to the elevated doses of fertilizers applied in the FA. The use of high doses aimed to avoid growth restrictions due to nutrient shortfalls. This indicates that studies with fertilizer doses in FA in the coppice regime have a greater potential to achieve economic viability.

The operational fertilization in the coppice regime is only carried out after sprout thinning, which occurs at 12 months post-harvest, applying quantities of nutrients well below those of the tall shaft regime (Table 3). This marked reduction of the doses applied, associated with stress caused by the sprout thinning, eliminating between $50 \%$ and $70 \%$ of the biomass produced, is one of the factors that could explain the drop in productivity and the greater biological response to FA. Less productivity tends to present more significant responses to fertilizations in Eucalyptus stands (Ferreira \& Stape, 2010; Silva et al., 2016). Studies in stands managed according to a coppice regime have shown lower productivity in relation to the tall shaft regime (Miranda et al., 1998a, b; Faria et al., 2002). The authors argue that part of the drop in productivity of these stands results from nutritional deficiencies generated by the exportation of nutrients. These nutritional limitations can be minimized if the harvest is restricted to the wood, leaving all the residue in the area (Santana et al., 2002).

When comparing the two extremes of response to the same FA by region, in the tall shaft regime we can infer that greater water availability favors production (Tables 1 and 5). To demonstrate this effect, regions R2 and R3 were selected, since they possess all the age classes evaluated. A greater response to fertilization in regions with greater water availability is widely reported in the literature (Smethurst et al., 2003; Stape et al., 2010; Silva et al., 2016).

Greater responses to the FA was observed during development in forests with tall shaft regimes, in other words, the younger the age, the greater the response observed. Stands with 2.5 years (CLI 1) are nearer to the canopy closure stage. This stage tends to show a greater leaf area index (Smethurst et al., 2003; Laclau et al., 2010), consequently, there is a greater demand for nutrients. The lower response to FA at more advanced ages can be attributed to the establishment of nutrient cycling (Santana et al., 2008; Gonçalves et al., 2013) and of operational fertilization that adopted the nutritional balance model where one does not expect nutritional restrictions. Some authors report greater responses to FA at advanced ages in studies with twin-plots (Stape et al., 2006; Ferreira \& Stape, 2010; Silva et al., 2016) where nutritional restrictions were observed using limited quantities of nutrients applied during operational fertilization.

The probability of the response to the FA can be employed to classify the stands with greater or lesser potential for response (Fisher \& Binkley, 2000). In the present study, approximately $37 \%$ of the plots presented a greater potential for biological response to the FA in both regimes evaluated (Figure 3). This highlights that applying the same fertilization indiscriminately without considering regional quality may not generate the best outcomes. It is common in Brazilian Eucalyptus cultivation to apply similar quantities of nutrients in locations with distinct potentials in the response, a fact that can compromise economic returns.

The FA applied at advanced ages where operational fertilization was established employing the nutritional balance method shows that starting from 2.5 years of age there was no economic benefit, despite the biological response. To better exploit the potential of this type of fertilization, its application, taking into account different levels and dosages in a sequence of ages between six and 30 months, can demonstrate the viability or not of the response to fertilization at advanced ages.

\section{CONCLUSION}

Fertilization at advanced age presented a biological response and provided volumetric gains for stands managed according to tall shaft and coppice regimes.

- Stands with a coppice regime possess greater potential for biological response to fertilization at an advanced age.

- Despite the biological response, the volumetric gains did not provide a financial return in either regime due to the elevated doses applied. 


\section{ACKNOWLEDGEMENTS}

We would like to thank Universidade Federal dos Vales do Jequitinhonha e Mucuri - UFVJM; Conselho Nacional de Pesquisa e Desenvolvimento - CNPq; Fundação de Amparo à Pesquisa de Minas Gerais FAPEMIG; This study was financed in party by the Coordenação de Aperfeiçoamento de Pessoal de Nível Superior - Brasil (CAPES). Gerdau Florestal S/A for the data base for this work.

\section{SUBMISSION STATUS}

Received: 27 oct., 2017

Accepted: 12 jul., 2018

\section{CORRESPONDENCE TO}

\section{Laís Silva}

Universidade Federal de Viçosa - UFV, Rodovia LMG 818, Km 6, CEP 35690-000, Florestal, MG, Brasil

e-mail: lais.graziele@ufv.br

\section{FINANCIAL SUPORT}

Universidade Federal dos Vales do Jequitinhonha e Mucuri - UFVJM; Conselho Nacional de Pesquisa e Desenvolvimento - CNPq; Fundação de Amparo à Pesquisa de Minas Gerais - FAPEMIG; This study was financed in party by the Coordenação de Aperfeiçoamento de Pessoal de Nível Superior - Brasil (CAPES) Finance Code 001. Gerdau Florestal AS for the data base for this work.

\section{REFERENCES}

Alvares CA, Stape JL, Sentelhas PC, Gonçalves JLM, Sparovek G. Köppen's climate classification map for Brazil. Meteorologische Zeitschrift (Berlin) 2013; 22(6): 711-728. http://dx.doi.org/10.1127/0941-2948/2013/0507.

Faria GE, Barros NF, Novais RF, Lima JC, Teixeira JL. Produção e estado nutricional de povoamentos de Eucalyptus grandis, em segunda rotação, em resposta à adubação potássica. Revista Árvore 2002; 26(5): 577-584. http://dx.doi.org/10.1590/S0100-67622002000500008.

Ferreira JMA, Stape JL. Productivity gains by fertilisation in Eucalyptus urophylla clonal plantations across gradients in site and stand conditions. Southern Forests: a Juornal of Forest Science 2010; 71(4): 253-258. http://dx.doi. org/10.2989/SF.2009.71.4.1.1028.

Fisher RF, Binkley D. Ecology and management of forest soils. Forests 2000; 6: 973-991.

Fundação Getúlio Vargas - FGV [online]. 2017 [cited 2017 Apr 25]. Available from: http://www.fgv.br

Gonçalves JLM, Alvares CA, Higa AR, Silva LD, Alfenas $\mathrm{AC}$, Stahl J et al. Integrating genetic and silvicultural strategies to minimize abiotic and biotic constraints in Brazilian eucalypt plantations. Forest Ecology and Management 2013; 301: 6-27. http://dx.doi.org/10.1016/j. foreco.2012.12.030.

Gonçalves JLM, Stape JL, Laclau JP, Bouillet JP, Ranger J. Assessing the effects of early silvicultural management on long-term site productivity of fastgrowing eucalypt plantations: the Brazilian experience. Southern Forests 2008; 70(2): 105-118. http://dx.doi.org/10.2989/SOUTH. FOR.2008.70.2.6.534

Instituto de Geociências Aplicadas - IGA [online]. 2015 [cited 2017 May 25]. Available from: http://www.iga.br/ siteiga/mapas/cgi/Imagens/Localizacao_MG.pdf

Kimberley MO, Wang H, Wilks PJ, Fisher CR, Magesan GN. Economic analysis of growth response from a pine plantation forest applied with biosolids. Forest Ecology and Management 2004; 186(1-3): 345-351. http://dx.doi. org/10.1016/j.foreco.2003.09.003.

Laclau J-P, Ranger J, Gonçalves JLM, Maquère V, Krusche AV, M'Bou AT et al. Biogeochemical cycles of nutrients in tropical Eucalyptus plantations main features shown by intensive monitoring in Congo and Brazil. Forest Ecology and Management 2010; 259(9): 1771-1785. http://dx.doi. org/10.1016/j.foreco.2009.06.010.

Meneses VA, Trugilho PF, Calegario N, Leite HG. Efeito da idade e do sítio na densidade básica e produção de massa seca de madeira em um clone do Eucalyptus urophylla. Scientia Forestalis 2015; 43(105): 101-116.

Miranda GA, Barros NF, Leite HG, Couto L, Filho MN. Produtividade de povoamento de eucalipto em regime de talhadia, em função da adubação parcelada no Vale do Jequitinhonha- MG. Revista Árvore 1998b; 22(1): 51-59.

Miranda GA, Barros NF, Leite HG, Couto L, Teixeira JL. Produção de povoamentos de eucalipto em regime de talhadia, em função da adubação e da distribuição da galhada da rotação anterior, no vale do Jequitinhonha MG. Revista Árvore 1998a; 22(3): 307-314.

Nascimento V, Arf O, Tarsitano MAA, Garcia NFS, Penteado MS, Sabundjian MT. Economic analysis of rice and common bean production in succession to green manure crops and mecahnical soil decompression in Brazilian Savannah. Revista Ceres 2016; 63(3): 315-322. http://dx.doi.org/10.1590/0034-737X201663030006.

Özçelik R, Diamantopoulou MJ, Crecente-Campo F, Eler U. Estimating crimean juniper tree height using nonlinear 
regression and artificial neural network models. Forest Ecology and Management 2013; 306: 52-60. http://dx.doi. org/10.1016/j.foreco.2013.06.009.

Santana RC, Barros NF, Neves JCL. Eficiência de utilização de nutrientes e sustentabilidade da produção em procedências de Eucalyptus grandis e Eucalyptus saligna em sítios florestais do estado de São Paulo. Revista Árvore 2002; 26(4): 447-457. http://dx.doi.org/10.1590/ S0100-67622002000400007.

Santana RC, Barros NF, Novais RF, Leite HG, Comerford NB. Alocação de nutrientes em plantios de eucalipto no Brasil. Revista Brasileira de Ciência do Solo 2008; 32(spe): 2723-2733. http://dx.doi.org/10.1590/S010006832008000700016 .

Shumacher FX, Hall FS. Logarithmic expression of timber-tree volume. Journal of Agricultural Research 1933; 7(9): 719-734.

Silva PHM, Poggiani F, Libardi PL, Gonçalves AN. Fertilizer management of eucalypt plantations on sandy soil in Brazil: Initial growth and nutrient cycling. Forest Ecology and Management 2013; 301: 67-78. http://dx.doi. org/10.1016/j.foreco.2012.10.033.
Silva RML, Hakamada RE, Bazani JH, Otto MSG, Stape JL. Fertilization response, light use, and growth efficiency in Eucalyptus plantations across Soil and climate gradients in Brazil. Forests 2016; 7(12): 117. http://dx.doi.org/10.3390/ f7060117.

Smethurst P, Baillie C, Cherry M, Holz G. Fertilizer effects on LAI and growth of four Eucalyptus nitens plantations. Forest Ecology and Management 2003; 176(1-3): 531-542. http://dx.doi.org/10.1016/S0378-1127(02)00226-8.

Stape JL, Binkley D, Jacob WS, Takahashi EN. Twin-plot approach to determine nutrient limitation and potential productivity in Eucalyptus plantations at landscape scales in Brazil. Forest Ecology and Management 2006; 223(1-3): 358-362. http://dx.doi.org/10.1016/j.foreco.2005.11.015.

Stape JL, Binkley D, Ryan MG, Fonseca S, Loos RA, Takahashi EN et al. The Brazil eucalyptus potential productivity project: Influence of water, nutrients and stand uniformity on wood production. Forest Ecology and Management 2010; 259(9): 1684-1694. http://dx.doi. org/10.1016/j.foreco.2010.01.012.

Statsoft. Statistica - data analysis software system. Version 10.0 [online]. Palo Alto: Statsoft Inc; 2010 [cited 2017 Apr 25]. Available from: www.statsoft.com 